\title{
Geographic Distribution and Morphometric Differentiation of Triatoma nitida Usinger 1939 (Hemiptera: Reduviidae: Triatominae) in Guatemala
}

\author{
Carlota Monroy $/^{+}$, Dulce María Bustamante, Antonieta Rodas, Regina Rosales ${ }^{\dagger}$, \\ Mildred Mejía, Yuichiro Tabaru*
}

\begin{abstract}
Escuela de Biología, Facultad de Ciencias Químicas y Farmacia, Universidad de San Carlos, Edificio T-10, $2^{\circ}$ nivel, Ciudad Universitaria, Zona 12, Ciudad de Guatemala, Guatemala *Japanese International Cooperation Agency, Matsudo City, Chiba, Japan
\end{abstract}

Triatoma nitida was found in 14 (0.4\%) out of 3,726 houses located in six departments across Guatemala, which were surveyed from 1994 to 1998 by the man-hour collection method. Compared to previous information, the distribution of T. nitida in Guatemala has increased from five to nine departments; the species is present in mild climates at altitudes from 960 to $1,500 \mathrm{~m}$. Fourteen percent of the intradomestic $\mathrm{T}$. nitida were infected with Trypanosoma cruzi. The species was often found in conjunction with other triatomines (T. dimidiata and Rhodnius prolixus). The domestic and peridomestic presence of T. nitida in Guatemala was rare, but occasionally this species was colonizing human-made constructions. T. nitida appears to have a low importance as Chagas disease vector in Guatemala, as indicated by its scarce presence in the domestic habitats and defecation patterns. However, it clearly has potential to become a Chagas vector so we recommend an on-going study of the intradomestic presence of $\mathrm{T}$. nitida following the control programs in Guatemala.

Morphometric analysis of $47 \mathrm{~T}$. nitida males from three localities showed quantitative differences between the populations, which indicates that geographic distance is an important factor in the structuring of $\mathrm{T}$. nitida populations.

Key words: Triatoma nitida - Chagas disease - geographic distribution - altitudinal distribution - morphometrics - Guatemala

Triatoma nitida Usinger 1939 is distributed throughout Mexico, Guatemala, Honduras and Costa Rica, and has been found naturally infected with Trypanosoma cruzi (Lent \& Wygodzinsky 1979). In Costa Rica, T. nitida is a sylvatic species, with adults occasionally invading domestic habitats but apparently unable to colonize these habitats, therefore it is not considered an important Chagas disease vector in that country (Zeledón 1983). One report exists of domestic colonization showing three adults and one nymph in a house in Costa Rica (Vargas \& Montero-Gei 1971).

In Mexico, T. nitida was collected in a horse stable in the state of Yucatan, where all the bugs were positive for T. cruzi (González-Angulo \& Ryckman 1967). In the state of Oaxaca, two adults and one nymph of T. nitida were collected in domestic habitats by homeowners in two out of 92 surveyed villages. The authors attribute the presence of this species outside the Yucatan Peninsula to the passive transfer of bugs carried by migrant farm workers (Ramsey et al. 2000).

This work was supported by the Project of Investigation of Tropical Diseases under the Technical Cooperation between Guatemala and Japan and by UNDP/World Bank/WHO Special Program for Research and Training in Tropical Diseases.

${ }^{+}$Corresponding author. Fax: +502-4769856. E-mail: cmonroy@usac.edu.gt, carlotamonroy@yahoo.com.

†Deceased 19 August 2002

Received 3 June 2002

Accepted 7 November 2002
In Guatemala, Chagas disease was first reported in areas where T. nitida and Triatoma dimidiata were both present (Reichenow 1933). In later studies, T. nitida was seldom observed (Blanco 1943), but a high infection rate of 83\% with T. cruzi was reported by De León (1943). Peñalver (1953) included T. nitida together with $T$. dimidiata and Rhodnius prolixus, as the main vectors of Chagas disease in the country. A recent study reported the presence of T. nitida from inside houses (Tabaru et al. 1999). However, the real vectorial importance of this species in Guatemala has not been established.

The biology of T. nitida has been studied under laboratory conditions (Galvão et al. 1995, 1996). Of note, this species has one of the longest life cycles among the Triatominae, with an average of 897.5 days; it is also characterized by a high number of feedings between life stages, which is an important fact in terms of vectorial capacity because it increases the probability of infection and transmission of T. cruzi. However, T. nitida seldom defecates immediately after blood meals, which reduces its vectorial capacity (Galvão et al. 1995). T. nitida also has a great capacity to survive fasting, an aspect of epidemiological relevance because starved insects can survive and move to more favorable environments, creating new infectious foci (Galvão et al. 1996).

With respect to systematic and morphological aspects, studies have focused on the characterization of the species in order to clarify its taxonomic status in relation to Triatoma neotomae. Intermediate forms between this two species have been reported (Lent \& Wygodzinsky 1979). Four male external genitalia characters were proposed to 
distinguish between these species (Lent \& Jurberg 1992), and detailed descriptions of the egg chorium and the external morphology of the nymphs were made to increase the number of parameters that could be used to distinguish T. nitida and T. neotomae (Jurberg et al. 1991).

In this paper we discuss the importance of T. nitida as Chagas disease vector in Guatemala. Based on information derived from several years of entomological surveys, we analyze the geographic distribution of the species, its infection rates and colonization patterns in human dwellings. In addition, we examine the T. nitida intraspecific variation, using morphometry as a tool to compare three populations from different localities, in order to understand the population structuring of the species.

\section{MATERIALS AND METHODS}

Geographic distribution - From 1994 to 1997, we searched for triatomine bugs in 2,809 houses over all of the 22 departments of Guatemala (Tabaru et al. 1999), and $T$. nitida was never found in altitudes below $950 \mathrm{~m}$ above sea level (m.a.s.l.). Therefore during 1997 and 1998, 917 new houses were examined, all above this altitude. The triatomine bugs collections were made using the traditional man-hour method, with two people searching in each house for $30 \mathrm{~min}$ with the help of flashlights and forceps; only houses constructed with materials suitable for triatomine bugs colonization were inspected. A questionnaire was completed for each house with relevant information about numbers of human inhabitants, house construction materials and the presence of domestic animals. The altitude above sea level in each village was recorded with an altimeter. The collected bugs were taken to the laboratory and dissected to assess the presence of T. cruzi in the rectal and intestinal contents. The rectum and intestine of each bug was dispersed in saline solution (phosphate buffer), and inspected under 400X magnification by a trained technician for 2 min for the presence of $T$. cruzi.

From 1999 to 2002, after the finalization of the systematic searches we made some entomological surveys and we detected T. nitida in some new sites.

Morphometrics - A total of 47 T. nitida males were analyzed. Three populations were compared using traditional morphometric methods (Rohlf \& Marcus 1993). Twenty four insects were collected in a chicken coop in Las Palmas, Olopa, department of Chiquimula; 13 were the first generation from a laboratory culture, with domiciliary parents collected in San Cristobal, Villa Canales, department of Guatemala. The remaining 10 bugs were collected in the department of Quiche, one of them was found in a cave (municipality of Sacapulas) and the rest are from a chicken coop (municipality of Canilla). The left hemelytra (front wings) of the insects were removed and mounted on microscope slides. A digital image of each wing was obtained using a dissection microscope (at 24X) connected to a computer by means of a camera. The images were acquired in the tpsDig 1.27 program (Rohlf 2001), where the locations (x, y coordinates) of six landmarks were marked for each wing (Fig. 1). From the coordinates, the six following interlandmark distances were calculated in a electronic sheet by means of the Pythagoras theorem:
1-2, 1-3, 3-4, 4-5, and 5-6. The same investigator did the entire procedure. The distances values were transformed into $\log$ values and size correction procedures (Rohlf 1990) were applied to the data matrix with the purpose of reducing the individual variation within the populations, which is result of the static allometry. The size effects were corrected following Klingenberg (1996) based on the common model of linear growth (Common Principal Components Analysis or CPCA). The distance-data matrix was compatible with the model $\left(\chi^{2}=31.239 ; \mathrm{P}=0.052\right)$, and a CPCA was computed. The CPC scores are considered as an estimate of within-group variation and were used as variables in a canonical discriminate analysis (CDA), except for CPC1 which is an estimate of the common allometric pattern (Klingenberg 1996). The results were graphically represented in a scatter plot using the first two canonical discriminant functions as axes; the individuals belonging to the same group were enclosed in a polygon. Following Dujardin and LePont (2000), the statistical significance of the CDA analysis was estimated by the Wilks' Lambda statistics and the agreement between the observed and expected classifications was measured with the Kappa statistics. SPSS for Windows 10.1.0 (SPSS Inc. 1999) software was used to perform the CDA analysis. For CPCA calculations, the NTSys pc 2.02j (Rohlf 2000) software was used.

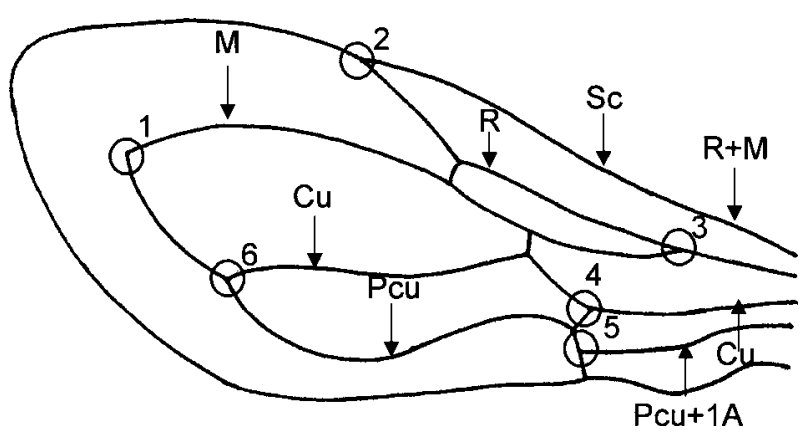

Fig. 1: left hemelytron of Triatoma nitida showing the six landmarks, which locations ( $x, y$ coordinates) were acquired in the tpsDig 1.27 program (Rohlf 2001). The landmarks represent intersections between two or three wing veins. The veins are M: media; $\mathrm{Cu}$ : cubitus; Pcu: poscubitus; 1A: first analis; R: radius; Sc: subcosta (Lent \& Wygodzinsky 1979)

\section{RESULTS}

Out of all 22 Guatemalan departments surveyed, T. nitida was found only in eight departments: Alta Verapaz, Chiquimula, Guatemala, Huehuetenango, Jalapa, Jutiapa, Quiche and Santa Rosa (Fig. 2), between 960 to 1500 m.a.s.l.

In total, 92 T. nitida were found in 14 houses out of $3726(0.4 \%)$ in nation-survey (Table I). In eight of the 14 houses, only one bug was found. The species was seldom alone: in seven out of 14 houses T. nitida was together with $T$. dimidiata, in two houses with $R$. prolixus. T. nitida was most often collected (79\%) inside walls of bajareque (mud and stick) or adobe (Table I), and the remainder found on mattresses (21\%). Thirteen of the $92 \mathrm{~T}$. 
nitida (14\%) collected inside human dwellings were infected with $T$. cruzi.

With respect to the peridomestic environment, T. nitida was detected in two chicken coops in Las Palmas, Olopa, department of Chiquimula. In the first chicken coop three bugs were collected (one fourth instar nymph and two fifth instars); in the second, 78 bugs were collected, as follows: 22 females, 19 males, 17 fifth instars, 9 fourth instars, 10 third instars, and one second instar. From the second chicken coop, 38 bugs were dissected for T. cruzi inspection and three adults and two nymphs were found positive $(13 \%)$.

Between the years 2000 and 2002, we found 96 T. nitida in three departments of Guatemala (Table II). Not all of these insects were inspected for T. cruzi infection, but of 15 bugs from San Isidro, nine bugs from Tuxtunep and three sylvatic bugs from Sacapulas, none of them was positive for the parasite.

With respect to the morphometric comparisons between three T. nitida populations, the canonical discriminant analvsic results were hiohlv sionificant /Wilks' I amda
$=0.263, \mathrm{p}=0.000)$ and produced almost perfect discrimination of the individuals from each group (Table III). After the removal of within-group allometric influences, the discrimination on allometry-free variables showed significant differences of the "wing form" (Dujardin \& LePont 2000) between the three populations (Fig. 3).

\section{DISCUSSION}

T. nitida was previously reported in Guatemala in the departments of Baja Verapaz, Alta Verapaz, Chiquimula, Jalapa and Guatemala (Peñalver 1953, Tabaru et al. 1999). This is the first report of the presence of this species in the departments of Huehuetenango, Jutiapa, Quiche and Santa Rosa. All the sites where T. nitida was present are located between 960 and $1500 \mathrm{~m}$ altitude. In Guatemala, domestic triatomines are in most cases present between 800 and $1600 \mathrm{~m}$, and seldom above this altitude (Tabaru et al. 1999). There is a similar report for T. nitida in Oaxaca, Mexico, where only three insects were collected by homeowners in two out of 92 surveyed villages, within an altitude range of 1100 to 1520 m.a.s.l. (Ramsev et al. 2000).

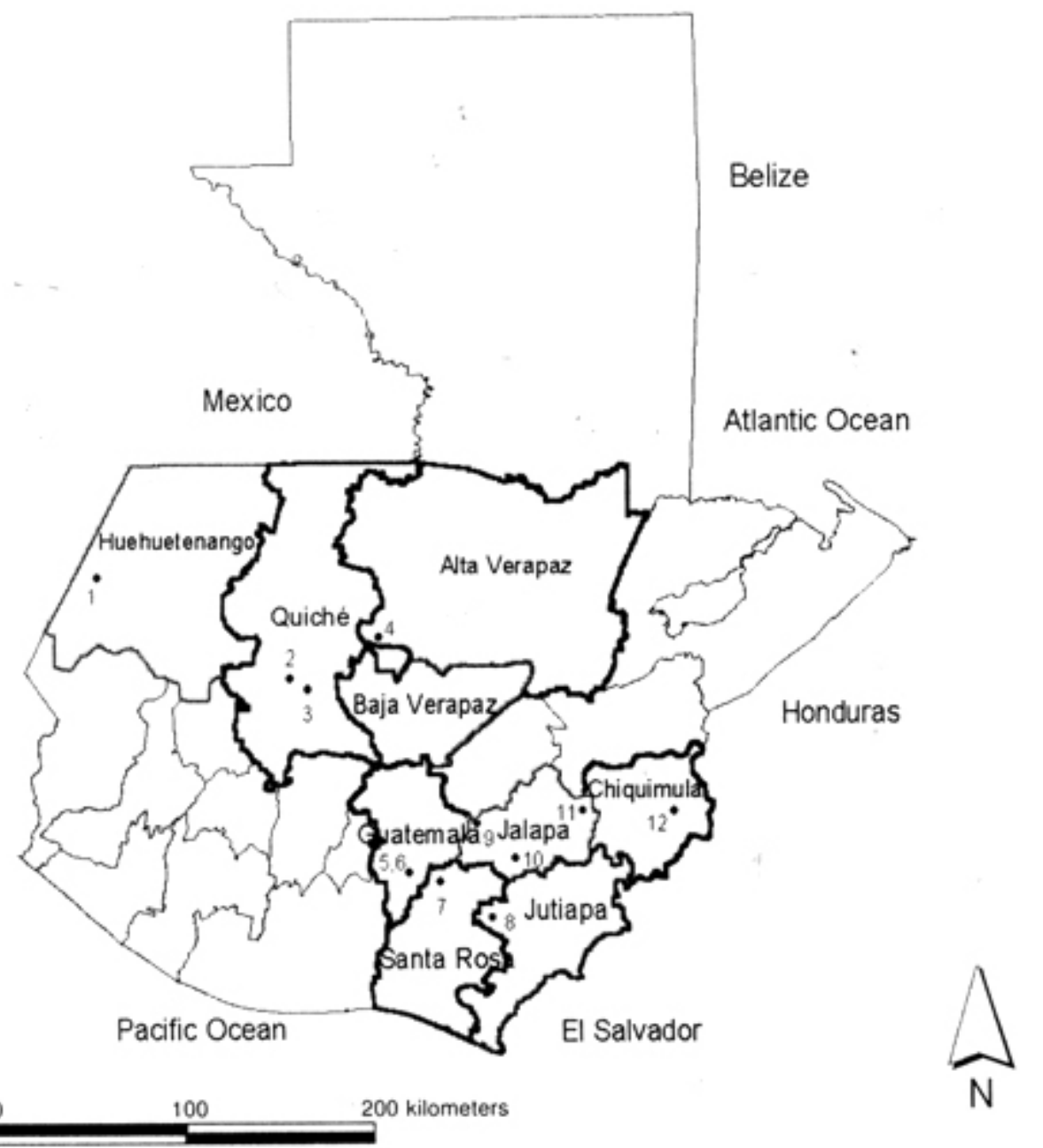

Fig. 2: map of Guatemala showing the nine departments where Triatoma nitida have been collected, and some of the localities where it was collected in this study (see Tables I and II). Localities: 1. San Isidro, La Democracia; 2. San Andrés Sajcabajá, San Andrés Sajcabajá; 3. Chamop, San Bartolomé Jocotenango; 4. Santa Elena, San Cristóbal; 5-6. Santa Rosita and San Cristobal, Villa Canales. 7. Primera Sabana, Santa Rosa de Lima; 8. El Copante, San Jose Acatempa; 9. Laguna Verde, Jalapa; 10. San Juan Salamos, Monjas; 11. Pie de La Cuesta, San Pedro Pinula; 12. Las Palmas, Olopa 
The intradomestic presence of T. nitida in Guatemala was proven to be rare, and in most cases only one bug per house and per village was found (Table I). Previous reports from Costa Rica (Vargas \& Montero-Gei 1971) and Mexico (Ramsey et al. 2000) also indicate small numbers of these bugs inside human dwellings. However, in two houses an unusually large number of bugs were found (24 and 39), which is not commonly seen even with the more ubiquitous species $T$. dimidiata (Monroy et al. 1998a). The age distributions of the T. nitida bugs from these two houses, where both adults and nymphs were found, let us suggest that $T$. nitida is able to colonize human dwellings in Guatemala. The presence of T. nitida in the peridomestic environment was not common, but we did observe three chicken coops with a relatively high abundance $(78,28$ and 18) of bugs, in Chiquimula and Quiche; this observations support that T. nitida can colonize human-made constructions.
T. nitida was present in houses of various types of construction, but inside the houses the bugs were found mainly on mud walls (79\%). In the chicken coops, some bugs were found in the roof.

The species was often found in conjunction with $T$. dimidiata and $R$. prolixus. In a previous study (Monroy et al. 1998b) we reported the case of one house where $T$. dimidiata and T. nitida were found together. In this house, T. dimidiata bugs were nine times more abundant and mainly positioned close to beds and chicken nests, while the specimens of $T$. nitida were dispersed throughout the house, probably compelled to disperse from suitable sites because of the competition with $T$. dimidiata.

Following Chagas control programs in Guatemala it is expected a diminution of the intradomestic presence of other triatomines (T. dimidiata, $R$. prolixus), the possibility exists in some areas that $T$. nitida could invade and colonize the empty microhabitats, based on our previous

TABLE I

Intradomestic presence of Triatoma nitida in 14 houses from 6 departments of Guatemala

\begin{tabular}{|c|c|c|c|c|c|c|c|c|}
\hline \multirow{2}{*}{$\begin{array}{l}\text { Collection site, location } \\
\text { (lat/long) - altitude (m) }\end{array}$} & \multicolumn{7}{|c|}{$\begin{array}{c}\text { T. nitida } \\
\text { (positive for Trypanosoma cruzi) }\end{array}$} & \multirow{2}{*}{$\begin{array}{c}\text { House } \\
\text { construction } \\
\text { materials: wall - roof }\end{array}$} \\
\hline & $\mathrm{M}$ & $\mathrm{F}$ & $5^{\circ}$ & $4^{\circ}$ & $3^{\circ}$ & $2^{\circ}$ & $1^{\circ}$ & \\
\hline $\begin{array}{l}\text { Santa Elena, San Cristóbal, Alta Verapaz } \\
15^{\circ} 22^{\prime} 30^{\prime \prime} / 90^{\circ} 37^{\prime} 45^{\prime \prime}-1,075\end{array}$ & & $\begin{array}{c}1 \\
(1)\end{array}$ & & & & & & $\begin{array}{r}\text { Bajareque }^{a}- \\
\text { Metal Sheet }\end{array}$ \\
\hline $\begin{array}{l}\text { Pie de la Cuesta, San Pedro Pinula, Jalapa } \\
14^{\circ} 40^{\prime} 08^{\prime \prime} / 89^{\circ} 44^{\prime} 13^{\prime \prime}-1,170\end{array}$ & & & $\begin{array}{c}1 \\
(0)\end{array}$ & & & & & $\begin{array}{l}\text { Bajareque - } \\
\text { Tile }\end{array}$ \\
\hline $\begin{array}{l}\text { Laguna Verde, Jalapa, Jalapa } \\
14^{\circ} 30^{\prime} 27^{\prime \prime} / 90^{\circ} 01^{\prime} 28^{\prime \prime}-1,440\end{array}$ & $\begin{array}{l}6 \\
(0)\end{array}$ & $\begin{array}{c}2 \\
(0)\end{array}$ & & $\begin{array}{c}2 \\
(0)\end{array}$ & $\begin{array}{l}19 \\
(0)\end{array}$ & $\begin{array}{l}3 \\
(0)\end{array}$ & $\begin{array}{l}7 \\
(0)\end{array}$ & $\begin{array}{l}\text { Bajareque - } \\
\text { Metal Sheet }\end{array}$ \\
\hline $\begin{array}{l}\text { San Juan Salamos, Monjas, Jalapa } \\
14^{\circ} 31^{\prime} 55^{\prime \prime} / 89^{\circ} 51^{\prime} 45^{\prime \prime}-960\end{array}$ & $\begin{array}{c}1 \\
(0)\end{array}$ & $\begin{array}{l}5 \\
(0)\end{array}$ & $\begin{array}{l}3 \\
(0)\end{array}$ & $\begin{array}{c}3 \\
(0)\end{array}$ & & & & $\begin{array}{l}\text { Adobe }{ }^{b}- \\
\text { Tile }\end{array}$ \\
\hline $\begin{array}{l}\text { San Cristóbal, Villa Canales, Guatemala } \\
14^{\circ} 25^{\prime} 30^{\prime \prime} / 90^{\circ} 29^{\prime} 40^{\prime \prime}-1,470\end{array}$ & $\begin{array}{c}6 \\
(4)\end{array}$ & $\begin{array}{c}3 \\
(2)\end{array}$ & $\begin{array}{c}4 \\
(2)\end{array}$ & $\begin{array}{c}3 \\
(0)\end{array}$ & $\begin{array}{c}5 \\
(0)\end{array}$ & $\begin{array}{c}1 \\
(1)\end{array}$ & $\begin{array}{c}2 \\
(0)\end{array}$ & $\begin{array}{l}\text { Bajareque - } \\
\text { Metal Sheet }\end{array}$ \\
\hline Ibid & $\begin{array}{c}1 \\
(0)\end{array}$ & $\begin{array}{c}1 \\
(0)\end{array}$ & & & & & & $\begin{array}{l}\text { Bajareque - } \\
\text { Straw }\end{array}$ \\
\hline $\begin{array}{l}\text { Santa Rosita, Villa Canales, Guatemala } \\
14^{\circ} 24^{\prime} 56^{\prime} / 90^{\circ} 29^{\prime} 35^{\prime} \text { - } 1,450\end{array}$ & $\begin{array}{l}1 \\
(0)\end{array}$ & & & & & & & $\begin{array}{l}\text { Bajareque - } \\
\text { Straw }\end{array}$ \\
\hline $\begin{array}{l}\text { Primera Sabana, Santa Rosa de Lima, Santa Rosa } \\
14^{\circ} 25^{\prime} 14^{\prime \prime} / 90^{\circ} 212^{\prime} \text { - } 1,180\end{array}$ & & & & $\begin{array}{c}1 \\
(1)\end{array}$ & & & & $\begin{array}{l}\text { Bajareque - } \\
\text { Tile }\end{array}$ \\
\hline $\begin{array}{l}\text { Las Palmas, Olopa, Chiquimula } \\
14^{\circ} 40^{\prime} 44^{\prime \prime} / 89^{\circ} 18^{\prime} 55^{\prime \prime}-1,310\end{array}$ & & $\begin{array}{c}2 \\
(0)\end{array}$ & $\begin{array}{c}1 \\
(0)\end{array}$ & & & $\begin{array}{c}1 \\
(0)\end{array}$ & & $\begin{array}{l}\text { Palopique }{ }^{c}- \\
\text { Straw }\end{array}$ \\
\hline Ibid & $\begin{array}{c}1 \\
(0)\end{array}$ & $\begin{array}{c}1 \\
(0)\end{array}$ & & $\begin{array}{c}1 \\
(0)\end{array}$ & & & & $\begin{array}{l}\text { Adobe - } \\
\text { Tile }\end{array}$ \\
\hline Ibid & $\begin{array}{c}1 \\
(0)\end{array}$ & & & & & & & $\begin{array}{l}\text { Brick - } \\
\text { Tile }\end{array}$ \\
\hline $\begin{array}{l}\text { Los Apantes, Olopa, Chiquimula } \\
?-1,500\end{array}$ & & & $\begin{array}{l}1 \\
(1)\end{array}$ & & & & & $\begin{array}{l}\text { Bajareque - } \\
\text { Metal Sheet }\end{array}$ \\
\hline $\begin{array}{l}\text { San Andrés Sajcabajá, San Andrés Sajcabajá, Quiché } \\
15^{\circ} 10^{\prime} 31^{\prime \prime} / 90^{\circ} 56^{\prime} 36^{\prime \prime}-1,302\end{array}$ & $\begin{array}{c}1 \\
(1)\end{array}$ & & & & & & & $\begin{array}{l}\text { Bajareque - } \\
\text { Metal Sheet }\end{array}$ \\
\hline $\begin{array}{l}\text { Chamop, San Bartolomé Jocotenango, Quiché } \\
?-1,275\end{array}$ & $\begin{array}{c}1 \\
(0)\end{array}$ & & & & & & & $\begin{array}{l}\text { Adobe - } \\
\text { Tile }\end{array}$ \\
\hline
\end{tabular}

$a$ : Bajareque, walls made of mud and vegetable fiber on bamboo grills; $b$ : adobe, walls fitted with blocks made of mud and vegetable fiber; $c$ : palopique, walls made of corn stems; ?: missing data. 
observation of competition with T. dimidiata (Monroy et al. 1998b). We recommend on-going vigilance, especially in the department of Quiche, where the intradomestic colonization of $T$. dimidiata is not very high and more abundant in the peridomicile; also, the entomological surveys by the Ministry of Health in this department are showing that $T$. nitida is very common inside and outside the houses (Mr Guillermo Hernández, pers. commun.). We also found the first sylvatic focus of this species in the country in this department, in a small and isolated cave in Sacapulas.

With respect to $T$. cruzi infection, we found positive T. nitida collected in both domestic and peridomestic ecotopes, in adults and even nymphs. The T. cruzi infection in domiciliary $T$. nitida was more frequent in adults $(28 \%)$ than in nymphs (8\%); this is a general pattern for triatomines, since the bugs keep the infection along their life (Schofield 1994). One house in particular stands out, the house in Villa Canales, Guatemala was colonized by 24 T. nitida and $38 \%$ of these were infected with T. cruzi, so clearly $T$. nitida has the potential to become a Chagas vector. The presence of the parasite in bugs from a chicken coop suggests the contact with mammals, due to the bugs movement or the entrance of mammals into the coop.

The reported infection rate with $T$. cruzi (14\%) is comparatively low with respect to other species in Guatemala as T. dimidiata $(19.1 \%)$ and R. prolixus (20.6\%) (Monroy, unpublished observations). However, is similar to that reported for T. infestans (7-15\%) in an endemic area of Argentina (Asin \& Giojalas 1995), or for Triatoma brasiliensis "brasiliensis" (15\%) in Brazil (Costa et al. 1998). In spite of its infection rate, laboratory studies have shown that this specie presents one important characteristic that reduces its vectorial capacity. Under laboratory conditions only $26 \%$ of the blood meals were followed by defecations within 20 min and most of the bugs evacuate excreta far from the food source (Galvão et al.

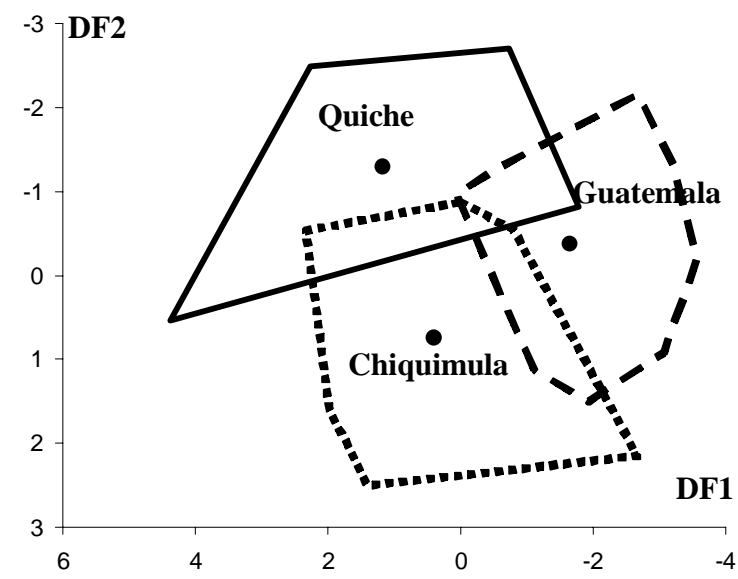

Fig. 3: canonical discriminate analysis of three Triatoma nitida populations from Guatemala, after the removal of allometric effects over five metric characters. The canonical discriminate factors 1 and 2 (DF1 and DF2) explained $62.5 \%$ and $37.5 \%$ of the variation, respectively. The points inside the polygons represent group centroids. The differences between group centroids were highly significant (Wilks' Lamda $=0.263, \mathrm{p}=0.000$ )

\section{TABLE III}

Classification results from the canonical discriminate analysis over five metric characters of the left hemelytron after the discount of allometric effects; $76.6 \%$ of the original grouped cases were correctly classified

$$
\text { (Kappa }=0.637, \mathrm{p}=0.000)
$$

Predicted group membership

\begin{tabular}{lcccc}
\cline { 2 - 4 } Observed & Chiquimula & Guatemala & Quiche & \\
\hline Chiquimula & 18 & 2 & 4 & 24 \\
Guatemala & 2 & 9 & 2 & 13 \\
Quiche & 0 & 1 & 9 & 10 \\
\hline
\end{tabular}

TABLE II

Triatoma nitida collections in some sites of Guatemala

\begin{tabular}{|c|c|c|c|c|c|c|c|c|c|}
\hline \multirow[t]{2}{*}{ Year } & \multirow{2}{*}{$\begin{array}{l}\text { Collection site, Location } \\
\text { (lat/long) - altitude (m) }\end{array}$} & \multicolumn{7}{|c|}{ T. nitida } & \multirow[t]{2}{*}{ Ecotope } \\
\hline & & $\mathrm{M}$ & $\mathrm{F}$ & $5^{\circ}$ & $4^{\circ}$ & $3^{\circ}$ & $2^{\circ}$ & $1^{\circ}$ & \\
\hline 2000 & $\begin{array}{l}\text { San Isidro, La Democracia, Huehuetenango } \\
15^{\circ} 35^{\prime} 32^{\prime \prime} / 91^{\circ} 53^{\prime} 19^{\prime \prime}-1410\end{array}$ & 5 & 4 & 18 & 9 & 2 & & & Domestic \\
\hline 2001 & $\begin{array}{l}\text { El Copante, San José Acatempa, Jutiapa } \\
14^{\circ} 15^{\prime} 00^{\prime} / 90^{\circ} 06^{\prime} 40^{\prime \prime}-1350\end{array}$ & & 1 & & & & & & Domestic \\
\hline \multirow[t]{7}{*}{2002} & $\begin{array}{l}\text { Paquix, San Bartolomé Jocotenango, Quiché } \\
15^{\circ} 11^{\prime} 20^{\prime \prime} / 91^{\circ} 06^{\prime} 10^{\prime \prime}-1560\end{array}$ & 1 & & & & & & & Domestic \\
\hline & $\begin{array}{l}\text { Tuxtunep, Canillá, Quiché } \\
?-1223\end{array}$ & & & & & 1 & & & Domestic \\
\hline & Ibid & 5 & 5 & 10 & 6 & 2 & & & $\begin{array}{l}\text { Peridomestic } \\
\text { (Chicken coop) }\end{array}$ \\
\hline & Ibid & 2 & & 7 & 6 & 2 & 1 & & Ibid \\
\hline & Ibid & 2 & & & & & & & Ibid \\
\hline & Ibid & & & & & & 1 & & Ibid \\
\hline & $\begin{array}{l}\text { Sacapulas, Quiché } \\
\text { ? }\end{array}$ & & & 1 & 2 & 2 & 1 & & $\begin{array}{l}\text { Sylvatic } \\
\text { (Cave) }\end{array}$ \\
\hline
\end{tabular}

?: missing data 
1995). We observed in five houses infested only with $T$. nitida, that it was difficult to find fecal drops on the walls of the houses because they were very small spots restricted to the hiding places of the bugs. This is in stark contrast to houses where only T. dimidiata is present, which often shows large streaks of multiple drops that cover the walls (Monroy et al. 1998a).

During our field work we observed that $T$. nitida may be easily eradicated from the domestic habitat. After the second phase of this investigation, we returned six months later to the two houses in Jalapa that were infested with this species. The residents had cleaned the houses, removing the clutter and straightening up the furniture, clothes and food periodically, and we could no longer find T. nitida in this subsequent visit. We also sprayed seven houses (two in Guatemala, three in Chiquimula, one in Santa Rosa, and one in Jalapa) using lambdacyalothrine. Six months after the treatments, T. nitida bugs were not found in any of the treated houses.

The epidemiological importance of T. nitida as vector of Chagas disease appears to be low as indicated by its scarce presence in the domestic environment and defecation patterns. Also, the chemical control of this species appears to be feasible. However, it clearly has potential to become a Chagas vector so we recommend an on-going study of the intradomestic presence of T. nitida, specially in the department of Quiche, following the control programs in Guatemala.

With respect to the morphometric comparisons, they resulted in a good differentiation between the three $T$. nitida populations (Fig. 3). With the removal of size from our data, we intended to reveal patterns of variation that would be less influenced by environmental factors, hence more related to evolutionary divergence (Dujardin \& LePont 2000). The bugs of one of the compared populations were from a laboratory colony; however, we considered this bugs as proper material for population studies since they were the first generation and phenotypic variations arise in colonies but after several generations (Galíndez Girón et al. 1994); a reduction in size and a diminution of sexual dimorphism can be observed in colonies of at least 10 generations, but this is not still confirmed in lower generations (Jaramillo 2000).

The observed quantitative differences between the populations can be the result of evolutionary processes persuaded by the isolation derived from the altitudinal restriction in the distribution of $T$. nitida. Morphometric relationships in Triatominae have proved to correlate quite well with phylogenetic reconstruction (Dujardin et al. 1999). Hence, morphometry could be applied to study the relations between T. nitida and T. neotomae. Lent and Wygodzinsky (1979) propose that this closely related and morphologically similar species could be synonymous.

\section{ACKNOWLEDGEMENTS}

To Heberto Mauricio, Miguel Pérez, Reginaldo Pichillá and the personnel from the Área de Salud del Quiché for their field collection. To Patricia Dorn, Sergio Melgar, Cathleen Nakagawa, CJ Schofield and Francisco Panzera for reviewing the manuscript. To JP Dujardin, ECLAT and NeTropica for the support in the training on morphometrics.

\section{REFERENCES}

Asin SN, Giojalas LC 1995. Type of rectal contents and infectivity of domiciliary populations of Triatoma infestans (Hemiptera: Reduviidae) in Argentina. J Med Entomol 32: 399-401.

Blanco SE 1943. Contribución al Estudio de los Redúvidos Hematófagos de Guatemala, Thesis, Universidad de San Carlos, Guatemala, 54 pp.

Costa J, Ribeiro de Almeida J, Britto C, Duarte R, Marchon Silva V, da S Pacheco R 1998. Ecotopes, natural infection and trophic resources of Triatoma brasiliensis (Hemiptera, Reduviidae, Triatominae). Mem Inst Oswaldo Cruz 93: 7-13.

De León R 1943. La tripanosomiasis Americana o enfermedad de Chagas en Guatemala. Gaceta Médica Centroamericana 1: 57-60.

Dujardin JP, LePont F 2000. Morphometrics of a neotropical sandfly subspecies, Lutzomyia carrerai thula. CR Acad Sci Paris Life Sciences 323: 273-279.

Dujardin JP, Chavez T, Moreno JM, Machane M, Noireau F, Schofield CJ 1999. Comparison of isoenzyme electrophoresis and morphometric analysis for phylogenetic reconstruction of the Rhodniini (Hemiptera: Reduviidae: Triatominae). J Med Entomol 36: 653-659.

Galíndez Girón I, Valderrama A, Añez N, Márquez V, Torres E, Madrid S, Barazarte R, Márquez J, González R 1994. Algunos estudios morfométricos en los Triatominae. I. Rhodnius prolixus y Rhodnius robustus (Hemiptera, Reduviidae). Entomol Vect 1: 99-111.

Galvão C, Jurberg J, Cunha V, Pinto de Mello R 1995. Biologia do Triatoma nitida Usinger, 1939 em Laboratório (Hemiptera: Revuviidae). Mem Inst Oswaldo Cruz 90: 657-663.

Galvão C, Jurberg J, Lent H 1996. Resistência ao jejum de Triatoma nitida Usinger, 1939 em laboratório (Hempitera, Reduviidae, Triatominae). Mem Inst Oswaldo Cruz 91: 639640.

González Angulo W, Ryckman RE 1967. Epizootiology of Trypanosoma cruzi in southwestern America. IX. An investigation to determine the incidence of Trypanosoma cruzi infections in Triatominae and man on the Yucatan Peninsula of Mexico. J Med Entomol 4: 44-47.

Jaramillo N 2000. Partición en Tamaño y Forma de los Caracteres Métricos y su Interés en los Estudios Poblacionales Aplicados a los Triatominae, Thesis, Universidad de Antioquia, Medellín, Colombia, 125 pp.

Jurberg J, Galvão C, Mônika Barth O 1991. Estudo morfológico de ovos e ninfas de Triatoma nitida Usinger 1939 (Hemiptera, Reduviidae, Triatominae). Rev Brasil Biol 51: 365372.

Klingenberg CP 1996. Multivariate allometry. In LF Marcus, M Conti, A Loy, GJ Naylor, DE Slice (eds), Advances in Morphometrics. Proceedings of the NATO-ASI on Morphometrics, Plenum Pres, New York, p. 23-49.

Lent H, Jurberg J 1992. A comparative study of the male external genitalia of Triatoma neotomae Neiva, 1911 and Triatoma nitida Usinger, 1939 (Hemiptera: Reduviidae). Mem Inst Oswaldo Cruz 87: 123-130.

Lent H, Wygodzinsky P 1979. Revision of the Triatominae (Hemiptera, Reduviidae) and their significance as vectors of Chagas disease. Bull Am Mus Nat Hist 163: 125-520.

Monroy C, Mejía M, Rodas A, Hashimoto T, Tabaru Y 1998a. Assessing methods for the density of Triatoma dimidiata, the principal vector of Chagas disease in Guatemala. Med Entomol Zool 49: 301-307.

Monroy C, Mejía M, Rodas A, Rosales R, Horio H, Tabaru Y 1998b. Comparison of indoor searches with whole house 
demolition collections of the vectors of Chagas disease and their distribution. Med Entomol Zool 49: 195-200.

Peñalver LM 1953. Estado actual de la enfermedad de Chagas en Guatemala. Rev Col Med Guatemala 4: 294-308.

Ramsey JM, Ordoñez R, Cruz-Celis A, Alvear AL, Chavez V, Lopez R, Pintor, JR, Gama F, Carrillo S 2000. Distribution of domestic Triatominae and stratification of Chagas disease transmission in Oaxaca, Mexico. Med Vet Entomol 14: 19-30.

Reichnow E 1933. Sobre la Existencia de la Enfermedad de Chagas en Guatemala, Publicación de la Dirección General de Sanidad Pública, Guatemala, 24 pp.

Rohlf FJ 1990. Morphometrics. Annu Rev Ecol Syst 21: 299316.

Rohlf FJ 2000. NTSys pc, Version 2.02j, Exeter Software, Setauket, New York.
Rohlf FJ 2001. tpsDig, Version 1.27. Ecology and Evolution, State University of New York, New York.

Rohlf FJ, Marcus L 1993. A revolution in morphometrics. Trends in Ecol Evolution 8: 129-132.

Schofield CJ 1994. Triatominae. Biología y Control, Eurocommunica Publications, United Kingdom, 77 pp.

SPSS Inc 1999. SPSS ${ }^{\circ}$ Base 10.0 Applications Guide, USA, $426 \mathrm{pp}$.

Tabaru Y, Monroy C, Rodas A, Mejía M, Rosales R 1999. The geographical distribution of vectors of Chagas disease and population at risk of infection in Guatemala. Med Entomol Zool 50: 9-17.

Vargas M, Montero-Gei F 1971. Triatoma dispar Lent 1950 in Costa Rica. J Med Entomol 8: 454-455.

Zeledón R 1983. Vectores de la enfermedad de Chagas y sus características ecofisiológicas. Interciencia 8: 384-394. 